\title{
Hubungan Stres dan Kesejahteraan (Well-being) dengan Moderasi Kebersyukuran
}

\author{
Erlis Manita ${ }^{1}$, Marty Mawarpury ${ }^{2}$, Maya Khairani ${ }^{3}, \mathcal{E}$ Kartika Sari ${ }^{4}$ \\ 1,2,3,4Program Studi Psikologi, Fakultas Kedokteran, Universitas Syiah Kuala
}

\begin{abstract}
This study aimed to determine the correlation of stress and well-being with gratitude moderation in early adults in Aceh. The method of this research was carried out using a quantitative approach. This study involved 349 early adults ( 264 female, 85 male) with age range of $20-40$ years $(M=22.20)$ selected through the nonprobability sampling method with incidental sampling techniques. Individual's stress levels were measured using the Perceived Stress Scale, well-being was measured using the Warwick-Edinburgh Mental Well-being Scale, and gratitude was measured using the Skala Bersyukur Indonesia. Data were analyzed using moderated regression analysis to test the research hypothesis. The results showed that stress had a significant negative relationship to well-being ( $\beta 1=-0.788 ; p$ $<0.05)$, then gratitude was able to moderate the relationship of stress and well-being ( $\beta 3=$ 3.257; $p<0.05$ ). This study showed that there was a correlation between stress and wellbeing with gratitude moderation. It meant that grateful people focus on things that are grateful for every day, so that the impact on low stress levels and can improve individual well-being.
\end{abstract}

Keywords: aceh; early adult; gratitude; stress; well-being

Abstrak. Penelitian ini bertujuan untuk mengetahui hubungan stres dan kesejahteraan dengan moderasi kebersyukuran pada dewasa muda yang berdomisili di Aceh. Penelitian ini menggunakan pendekatan kuantitatif, yang melibatkan 349 responden dewasa muda (264 perempuan, 85 laki-laki) dengan rentang usia 20-40 tahun $(M=22,20)$, dipilih melalui metode nonprobability sampling dengan teknik incidental sampling. Tingkat stres individu diukur menggunakan Perceived Stress Scale, kesejahteraan diukur menggunakan The Warwick-Edinburgh Mental Well-being Scale, dan kebersyukuran diukur menggunakan Skala Bersyukur Indonesia. Data penelitian dianalisis menggunakan moderated regression analysis. Hasil analisis data menunjukkan bahwa stres memiliki hubungan negatif yang signifikan terhadap kesejahteraan $(\beta 1=-0,788 ; p<0,05)$, selanjutnya kebersyukuran mampu memoderasi hubungan stres dan kesejahteraan $(\beta 3=3,257 ; p<0,05)$. Penelitian ini menunjukkan bahwa terdapat hubungan antara stres dan kesejahteraan (well-being) dengan moderasi kebersyukuran. Hal ini bermakna bahwa individu yang bersyukur fokus terhadap hal-hal yang disyukuri setiap hari, yang berdampak pada rendahnya tingkat stres serta dapat meningkatkan kesejahteraan individu.

Kata kunci: aceh; dewasa muda; kebersyukuran; kesejahteraan; stres

Data berdasarkan Riset Kesehatan Dasar

${ }^{1}$ Korespondensi mengenai artikel ini dapat dilakukan melalui manita.erlis@gmail.com

2atau melalui marty@unsyiah.ac.id
(Riskesdas, 2018) prevalensi gangguan jiwa berat pada penduduk Indonesia naik secara signifikan dibandingkan dengan Riskesdas 2013 yaitu naik dari 1,7\%o 
menjadi $7 \%$ dan gangguan mental emosional naik dari $6 \%$ menjadi $9.8 \%$ dari jumlah penduduk Indonesia. Provinsi Aceh dan Yogyakarta merupakan daerah dengan prevalensi tertinggi sebesar 2,7\%o untuk gangguan jiwa berat (Riskesdas, 2013). Angka ini meningkat cukup signifikan yaitu 2,7\%o naik menjadi $9 \%$ (Riskesdas, 2018). Salah satu faktor risiko paling besar yang menyebabkan munculnya gangguan mental adalah stres (World Health Organization [WHO], 2013).

Lazarus dan Folkman (1984) yang mendefinisikan stres sebagai suatu hubungan antara individu dengan lingkungan yang dinilai oleh seseorang sebagai tuntutan atau ketidakmampuan dalam menghadapi situasi yang mengancam atau membahayakan. Stres adalah bagian dari kehidupan setiap individu. Siapa saja rentan mengalami stres, tidak dibatasi oleh usia, latar belakang pendidikan maupun pekerjaan. Survei yang dilakukan di Amerika menyatakan bahwa kelompok usia milenial (18 - 33 tahun) dan generasi X (34 - 47 tahun) adalah kelompok usia dengan rata-rata tingkat stres tertinggi (American Psychological Asssociation [APA], 2012). Rentang usia ini termasuk dalam rentang usia dewasa muda yaitu 20 sampai 40 tahun (Papalia, Olds \& Feldman, 1998). Dewasa muda menjadi periode perkembangan yang paling rentan mengalami stres, karena pada periode ini individu berada pada masa paling produktif, kecenderungan untuk mengeksplorasi hal-hal baru, dan mulai menerima tuntutan-tuntutan dari orang lain dan lingkungan sekitarnya yang pada akhirnya berdampak pada kelelahan fisik dan mental (Widodo, 2018). Oleh karena itu, pada penelitian ini difokuskan pada individu dengan rentang usia dewasa muda.

Situasi umum dalam kehidupan dinilai sebagai stres ketika tidak dapat diprediksi (unpredictable), tidak terkendali (uncontrollable), atau melebihi kapasitas (overloading). Stres yang dirasakan mencerminkan tingkat stres yang dialami sebagai fungsi dari peristiwa stres yang objektif, proses koping dan faktor kepribadian (Cohen, Kamarck, \& Mermelstein, 1983). Seseorang yang tidak mampu mengelola stres dengan tepat, maka akan berdampak buruk pada perilaku, kesehatan fisik maupun psikologisnya. Dampak pada perilaku misalnya makan secara berlebihan, makan makanan tidak sehat, minum minuman keras, dan merokok, sedangkan dampak psikologis misalnya perasaan depresi, cemas, membahayakan diri sendiri, munculnya perasaan dan pemikiran untuk bunuh diri, dan perasaan kesepian (Mental Health Foundation [MHF], 2018). Selain hal-hal yang disebutkan sebelumnya, stres ini juga akan berdampak pada kesejahteraan individu. Nezlek, Krejtz, Rusanowska, dan Holas pada tahun 2018 menyatakan bahwa tingkat kesejahteraan individu lebih tinggi ketika individu merasakan lebih sedikit stres dibandingkan ketika individu merasakan lebih banyak stres.

Kesejahteraan pada individu berkaitan juga dengan kondisi kesehatan mental. Shanafelt et al. (dalam Hartanto, 2016) menyebutkan bahwa dalam pandangan ilmu psikologi tradisional, keadaan sejahtera dan kondisi mental yang sehat berarti menggambarkan kondisi absennya stres, rasa bersalah dan bahkan depresi serta penguasaan diri terhadap simtom-simtom negatif lainnya. Era psikologi positif menggeser pandangan tersebut dan melengkapi definisi kesejahteraan (well-being) sebagai titik keberfungsian secara optimal sisi-sisi dalam diri individu yang mencakup: fisik, sosio-emotional, spiritual, kognitif, dan perilaku (Wajsblat dalam Hartanto, 2016). Secara bahasa, kesejahteraan 
diterjemahkan dari bahasa Inggris yaitu welfare, wellness, dan well-being. Penggunanaan kata welfare lebih sering digunakan dalam kajian ekonomi. Para ekonom (ahli ekonomi) menyebutkan konsep kesejahteraan (welfare) sebagai kepuasan terhadap preferensi atau keinginan (Brey, 2012). Sedangkan wellness dalam kamus Oxford didefinisikan sebagai keadaan sehat, dan kata well-being didefinisikan sebagai keadaan baik dalam kehidupan; kondisi bahagia, sehat, ataupun sejahtera (McMahon, Williams, \& Tapsell, 2010). Berdasarkan hal tersebut, maka yang dimaksud dalam penelitian ini adalah kesejahteraan (well-being). Kesejahteraan merupakan konstruk yang luas, yang dibagi ke dalam dua perspektif, yaitu perspektif hedonis berfokus pada kesejahteraan subjektif, yang sering disamakan dengan kebahagiaan, dan perspektif eudaimonic berfokus pada kesejahteraan psikologis (Ryan \& Deci, 2001).

Penelitian sebelumnya telah menemukan bahwa pengelolaan stres yang tepat dapat berdampak pada peningkatan kesejahteraan individu. Clemente, Hezomi, Allahverdipour, Jafarabadi, dan Safaian (2016) menemukan bahwa stres secara signifikan berhubungan dengan psychological wellbeing. Meskipun terdapat berbagai cara untuk meningkatkan kesejahteraan, penanaman rasa syukur dianggap sebagai dasar kepribadian positif, yang memungkinkan individu untuk menjalani kehidupan yang berkembang (a flourishing life) (Wood, Froh \& Geraghty, 2010). Konsep syukur yang terbentuk dalam individu tidak dapat dilepaskan dari proses pembelajaran yang mengarahkan pada satu nilai sangat erat dengan nilai budaya, agama maupun filosofi yang ada di sekitarnya (Haryanto \& Kertamuda, 2016). Listiyandini,
Nathania, Syahniar, Sonia, dan Nadya (2015) mendefinisikan syukur sebagai perasaan berterima kasih, bahagia, serta apresiasi atas hal-hal yang diperoleh selama hidup, baik dari Tuhan, manusia, makhluk lain, dan alam semesta, yang kemudian mendorong seseorang untuk melakukan hal yang sama seperti yang didapatkan.

Emmons dan Mishra (dalam Prabowo, 2017) menyatakan bahwa kebersyukuran (gratitude) adalah dasar kesejahteraan (well-being) dan kesehatan mental dalam rentang kehidupan manusia. Rasa syukur memengaruhi kesejahteraan secara langsung dan tidak langsung melalui dukungan sosial dan gaya koping (Lin \& Yeh, 2014). Beberapa literatur menyatakan bahwa rasa syukur atau mengingat hal-hal yang disyukuri dapat mendukung peningkatan yang signifikan terhadap kebahagiaan saat ini dan harapan dimasa yang akan datang (Witvliet, Richie, Luna, \& Tongeren, 2018).

Berdasarkan uraian fenomena permasalahan kesehatan mental dan pentingnya mengelola stres, penelitian ini bertujuan untuk mengetahui hubungan stres dengan kesejahteraan (well-being) melalui moderasi kebersyukuran.

\section{Metode}

Penelitian ini menggunakan metode kuantitatif yang bersifat korelasional, dengan menggunakan metode nonprobability sampling dengan teknik incidental sampling. Penelitian ini melibatkan tiga variabel yaitu variabel bebas (stres), variabel terikat (kesejahteraan) dan variabel moderator (kebersyukuran).

Penelitian ini melibatkan 349 partisipan berusia 20 hingga 40 tahun yang berdomisili di Aceh. Berdasarkan jenis kelamin, jumlah partisipan 
perempuan sebanyak 264 subjek $(75,6 \%)$, dan laki-laki sebanyak 85 subjek $(24,4 \%)$.

Metode pengumpulan data dalam penelitian ini menggunakan tiga skala, yaitu Perceived Stress Scale (PSS), The Warwick-Edinburgh Mental Well-being Scale (WEMWBS), dan Skala Bersyukur Indonesia. Metode analisis data yang digunakan dalam penelitian ini dengan menggunakan metode analisis moderated regression analysis untuk mengetahui hubungan stres dengan kesejahteraan dimoderasi oleh kebersyukuran.

Stres

Variabel stres dalam penelitian ini diukur menggunakan Perceived Stress Scale (PSS) yang dikembangan oleh Cohen dan Williamson (1988) untuk mengukur sejauh mana situasi dalam kehidupan individu dinilai sebagai stres. Skala ini dirancang untuk mengukur sejauh mana situasi dalam kehidupan individu dinilai sebagai stres. Skala ini terdiri dari 10 aitem yang dibuat berdasarkan pengalaman individu tentang apa yang dirasakan dalam hidup mereka. PSS-10 terdiri dari 10 aitem dengan 6 aitem favorable dan 4 aitem unfavorable. Penilaian dalam skala ini dilakukan dengan menggunakan skala Likert dengan lima alternatif pilhan jawaban yaitu, 0 tidak pernah, 1 hampir tidak pernah, 2 kadangkadang, 3 cukup sering, hingga 4 sangat sering. Cohen dan Williamson (1988) telah menguji Perceived Stress Scale menggunakan validitas konstruk. Sedangkan reliabilitas Perceived Stress Scale adalah sebesar $(\alpha)=0,804$.

Tabel 1.

Uji Analisis Regresi Sederhana (Persamaan 1)

\begin{tabular}{ccrrr}
\hline Variabel & Koefisien & Nilai Koefisien & $\boldsymbol{t}$-statistik & Sig- $\boldsymbol{t}$ \\
\hline (Constant) & $\mathrm{A}$ & 66,199 & 52,586 & 0,000 \\
Stres & $\beta 1$ & $-0,788$ & $-12,013$ & 0,000 \\
\hline$R^{2} 0,294$ Adjusted $R$-square $=0,292$ & $F=144,318$ & $n=349$ & Sig $=0,000 \leq 0,05$ & \\
\hline
\end{tabular}

Kesejahteraan (well-being)

Variabel kesejahteraan diukur menggunakan The Warwick-Edinburgh Mental Well-being Scale (WEMWBS) yang dikembangkan oleh Tennant et al. (2007). WEMWBS terdiri dari 14 aitem yang mengukur mental well-being dengan menggunakan skala Likert yaitu dengan menyediakan 5 pilihan jawaban ( $1=$ tidak pernah sama sekali, 5 = setiap waktu). Berdasarkan uji validitas dan reliabilitas, The Warwick-Edinburgh Mental Well-being Scale (WEMWBS) telah diuji validitas oleh Tennant et al. (2007) menggunakan validitas konstruk. Reliabilitas alat ukur ini adalah sebesar $(\alpha)=0,874$.

\section{Kebersyukuran}

Skala Bersyukur Indonesia yang dikembangkan oleh Listiyandini, et al., (2015) digunakan untuk mengukur kebersyukuran. Skala ini terdiri dari 30 aitem dengan 6 pilihan jawaban yang tersedia yaitu 1-6 (sangat tidak sesuai hingga sangat sesuai). Selanjutnya Listiyandini et al. (2015) menguji validitas Skala Bersyukur Versi Indonesia menggunakan validitas konstruk. Reliabilitas alat ukur Skala Bersyukur Indonesia adalah sebesar $(\alpha)=0,904$.

\section{Hasil}

Uji hipotesis penelitian dilakukan dengan menggunakan metode analisis moderated regression analysis. Hasil uji moderated regression analysis ditunjukkan oleh Tabel 1.

Berdasarkan Tabel 1, dapat dilihat bahwa nilai $F$ sebesar 144,318 dengan nilai 
signifikansi sebesar 0.000. Selanjutnya, hasil pengujian menunjukkan nilai koefisien $\beta 1$ sebesar $-0,788$ dengan nilai signifikansi sebesar $0,000(\leq 0,05)$, hal ini menunjukkan bahwa adanya hubungan negatif dan signifikan variabel stres terhadap kesejahteraan. Selain itu nilai adjusted $R^{2}$ adalah sebesar 0,292 menunjukkan bahwa sebesar 29,2\% variabel stres memengaruhi kesejahteraan, sedangkan sisanya 70,8\% variabel kesejahteraan dipengaruhi oleh variabel lain. Berdasarkan hasil dari analisa di atas, disimpulkan bahwa terdapat hubungan yang signifikan antara stres dengan kesejahteraan.

Tabel 2.

Uji Regresi Moderasi (Persamaan 2)

\begin{tabular}{ccccc}
\hline Variabel & Koefisien & $\begin{array}{c}\text { Nilai } \\
\text { Koefisien }\end{array}$ & t-statistik & \multicolumn{1}{c}{ Sig- $t$} \\
\hline (Constant) & $\mathrm{A}$ & 64,260 & 5,973 & 0,000 \\
Stres $(\mathrm{X} 1)$ & $\beta_{1}$ & $-1,997$ & $-4,189$ & 0,000 \\
Kebersyukuran $(\mathrm{X} 2)$ & $\beta_{2}$ & $-0,021$ & $-0,305$ & 0,761 \\
Interaksi (X1X2) & $\mathrm{B}_{3}$ & 0,010 & 3,257 & 0,001 \\
\hline$R^{2} 0,426 \quad$ Adjusted $R$-square $=0,421$ & $F 85,177$ & $n=349$ & Sig $0,000 \leq 0,05$ & \\
\hline
\end{tabular}

Hasil uji hipotesis dengan menggunakan moderated regression analysis dapat dilihat pada tabel 2. Nilai adjusted $R^{2}$ pada persamaan kedua yang merupakan persamaan moderasi memiliki nilai adjusted $R^{2}$ sebesar $42,6 \%$ berarti $57,4 \%$ dipengaruhi faktor lain diluar penelitian ini.

Nilai $F$ dari persamaan 2 yaitu 85,177 dengan nilai signifikasi 0,000 $\leq 0,05$ yang menunjukkan bahwa stres dan interaksi (stres dan kebersyukuran) secara bersama-sama memengaruhi kesejahteraan. Nilai interaksi koefisien $\beta 3$ sebesar 0,010 dan $t$-statistik 3,257 dengan tingkat signifikansi $0,001 \leq 0,05$ adalah signifikan. Hasil regresi dari hipotesis kedua ini menyatakan bahwa kebersyukuran memoderasi hubungan stres dan kesejahteraan.

\section{Diskusi}

Penelitian ini bertujuan untuk mengetahui hubungan antara stres dan kesejahteraan dengan moderasi kebersyukuran pada dewasa muda di Aceh. Berdasarkan hasil analisis data menunjukkan bahwa terdapat hubungan antara stres dan kesejahteraan dengan moderasi kebersyukuran pada dewasa muda di Aceh, dengan demikian hipotesis penelitian yang diajukan diterima.

Pada penelitian ini ditemukan 
Adapun dalam penelitian ini ditemukan persentase stres memengaruhi kesejahteraan adalah sebesar $29,2 \%$ dan $70,8 \%$ dipengaruhi oleh faktor-faktor lain. Ryff (dalam Ulfa, 2018) menyatakan bahwa ada banyak hal yang dapat memengaruhi kesejahteraan psikologis seseorang salah satunya adalah distres atau jenis stres yang memengaruhi seseorang ke segi negatif.

Pada penelitian ini ditemukan sebanyak 83 (23,78\%) subjek mengalami tingkat stres yang rendah, 238 (62.19\%) mengalami stres tingkat sedang, dan yang mengalami tingkat stres tinggi yaitu sebanyak $28 \quad(8,0 \%)$ dari 349 subjek penelitian. Berdasarkan hasil penelitian didapatkan bahwa sebagian besar individu memiliki tingkat stres pada tingkat sedang. Stres didefinisikan sebagai suatu hubungan antara individu dengan lingkungan yang dinilai oleh seseorang sebagai tuntutan atau ketidakmampuan dalam menghadapi situasi yang mengancam atau membahayakan (Lazarus \& Folkman, 1984). Berbagai hal dapat menjadi sumber stres atau penyebab munculnya stres pada setiap individu. Sumber stres ini sangat banyak dan sangat individual. Hal yang dapat menyebabkan munculnya stres juga bergantung pada persepsi individu terhadap suatu hal yang dialami (Segal, Smith, Segel \& Robinson, 2019). Sebagian besar individu mengalami stres pada suatu waktu dalam hidup, beberapa individu mengalami stres lebih sering daripada yang lain, dan beberapa individu mengalami kesulitan untuk menangani efeknya (Loseby, 2019).

Selanjutnya hasil uji analisis regresi moderasi menunjukkan bahwa kebersyukuran memoderasi hubungan antara stres dan kesejahteraan pada dewasa muda di Aceh. Persentase pengaruhnya sebesar $42,6 \%$ dan $57,4 \%$ dipengaruhi faktor lain di luar variabel dalam penelitian ini. Hasil penelitian ini didukung oleh penelitian sebelumnya oleh Nezlek, et al. (2018) yang menemukan bahwa kesejahteraan secara signifikan berhubungan dengan stres harian (daily stress), di mana kesejahteraan individu menjadi lebih tinggi ketika individu merasa tidak stres. Dalam penelitian tersebut juga menyebutkan bahwa kebersyukuran dapat menjadi penyangga dari efek stres, kebersyukuran memoderasi hubungan antara stres dan kesejahteraan. Studi ini menunjukkan bahwa ucapan terima kasih dan ekspresi merupakan intervensi yang bermanfaat untuk meningkatkan kesejahteraan mahasiswa yang stres yang mengalami kesulitan penyesuaian. Selanjutnya Işık dan Ergüner-Tekinalp

menyebutkan ungkapan terima kasih atau syukur merupakan intervensi yang bermanfaat untuk meningkatkan kesejahteraan mahasiswa yang stres dan mengalami kesulitan penyesuaian.

Pada skala bersyukur Indonesia ditemukan sebanyak $304(87,1 \%)$ dari 349 subjek penelitian memiliki tingkat kebersyukuran yang tinggi. Sedangkan untuk kesejahteraan dalam penelitian ini ditemukan sebanyak 214 (61,3\%) subjek penelitian memiliki kesejahteraan yang tinggi, 127 (36,4\%) subjek memiliki tingkat kesejahteraan pada kategori sedang, dan 8 $(2,3 \%)$ subjek memiliki tingkat kesejahteraan yang rendah. Hasil dari skala tersebut menggambarkan bahwa sebagian besar dari jumlah keseluruhan subjek penelitian memiliki kesejahteraan yang tinggi. Krejtz, Nezlek, Michnicka, Holas dan Rusanowska (2016) menemukan bahwa individu yang fokus setiap hari pada hal-hal yang mereka syukuri mengurangi reaksi mereka terhadap stres. Kebersyukuran merupakan emosi yang dirasakan ketika seseorang menyadari hal baik yang terjadi 
dalam hidup dan mengapresiasinya (Alkozei, Smith, \& Killgore, 2017).

Aisyah dan Chisol (2018) dalam penelitiannya menyebutkan bahwa individu yang banyak bersyukur akan berdampak pada kesejahteraan psikologis yang tinggi karena individu yang bersyukur akan mempunyai penilaian kognitif dan afektif yang positif terhadap kehidupannya, sebaliknya individu yang jarang bersyukur, maka akan mengalami gangguan kesejahteraan psikologis, sehingga kurang mampu melakukan penilaian kognitif dan afektif terhadap hidup yang dijalaninya.

Kebersyukuran merupakan salah satu aspek dari kesejahteraan pada masyarakat Indonesia, dimana rasa syukur mengacu pada reaksi emosional positif terhadap bantuan dari orang lain, bantuan untuk diri sendiri atau untuk apa yang telah dicapai seseorang. Rasa terima kasih berkontribusi pada rasa kepuasan dan merupakan fondasi kunci dari kebahagiaan (Haryanto \& Kertamuda, 2016). Menerima hidup dan bersyukur atas apa yang telah dicapai mengarah pada kehidupan yang tenang dan damai sehingga mengarah pada rasa kepuasan dan kesejahteraan yang mendalam (Haryanto \& Kertamuda, 2016).

\section{Kesimpulan}

Berdasarkan uji analisis yang telah dilakukan, hasil penelitian ini telah sesuai dengan tujuan penelitian yaitu untuk mengetahui hubungan antara stres dan kesejahteraan dengan moderasi kebersyukuran pada dewasa muda di Banda Aceh. Hasil penelitian ini menggambarkan bahwa individu yang bersyukur fokus terhadap hal-hal yang disyukuri setiap hari untuk mengatasi stres yang dialami, sehingga tingkat stres yang rendah mengurangi risiko munculnya dampak buruk pada individu dan juga dapat meningkatkan kesejahteraan individu.

Saran

Kepada peneliti selanjutnya yang ingin melakukan penelitian dengan variabel yang sama, maka dapat dilakukan dengan metode kualitatif melalui observasi dan wawancara untuk memperdalam hasil penelitian. Selain itu, peneliti selanjutnya dapat memperdalam aspek teori yang digunakan dan memperluas usia subjek penelitian.

\section{Kepustakaan}

Aisyah, A., \& Chisol, R. (2018). Rasa syukur kaitannya dengan kesejahteraan psikologi pada guru honorer sekolah dasar. Proyeksi, 13(2), 1-14. doi: 10.30659/jp.13.2.1-14

Alkozei, A., Smith, R., \& Killgore, W. D. S. (2017). Grateful people are happy and healthy-but why? Frontiers for Young Minds, 5(September), 1-9. doi: $\underline{10.3389 / \text { frym.2017.00055 }}$

American Psychological Asssociation (APA). (2012) Stress by Generation. Diakses melalui https://www.apa.org/news/press/rele ases/stress/2012/generations (pada 9 Oktober 2018)

Brey, P. A. E. (2012). Well-being in philosophy, psychology, and economics. In P. A. E. Brey, A. R. Briggle, \& E. H. Spence (Eds.), The Good Life in a Technological Age. (pp. 15-34). New York/London: Routledge.

Clemente, M., Hezomi, H., Allahverdipour, H., Jafarabadi, M. A., \& Safaian, A. (2016). Stress and psychological well-being: An explanatory study of the Iranian female adolescents. Journal of Child and Adolescent Behaviour, 4(1), 1-5. doi: $\underline{10.4172 / 2375-4494.1000282}$ 
Cohen, S., \& Williamson, G. (1988). Perceived stress in a probability sample of the United States. In S. Spacapan, \& S. Oskamp (Eds.), The Social Psychology of Health: Claremont Symposium on Applied Social Psychology (pp. 31-67). Newbury Park, CA: Sage.

Cohen, S., Kamarck, T., \& Mermelstein, R. (1983). A global measure of perceived stress. Journal of Health and Social Behavior, 24(4), 385-396. doi: 10.2307/2136404

Hartanto. (2016). Validitas dan reliabilitas Warwick-Edinburg mental well being scale. Counsellia: Jurnal Bimbingan dan Konseling, (2), 1-16. doi: $\underline{10.25273 / \text { counsellia.v6i2.1013 }}$

Haryanto, H. C., \& Kertamuda, F. E. (2016). Syukur sebagai sebuah pemaknaan. Insight: Jurnal Ilmiah Psikologi, 18(2), 109 . doi: 10.26486/psikologi.v18i2.395

Isik, S., \& Erguner-Tekinalp, B. (2017). The effects of gratitude journaling on Turkish first year college students' college adjustment, life satisfaction and positive affect. International Journal for the Advancement of Counselling, 39(2), 164-175. doi: 10.1007/s10447-017-9289-8

Krejtz, I., Nezlek, J. B., Michnicka, A., Holas, P., \& Rusanowska, M. (2016). Counting one's blessings can reduce the impact of daily stress. Journal of Happiness Studies, 17(1), 25-39. doi: 10.1007/s10902-014-9578-4

Lazarus, R. S., \& Folkman, S. (1984). Stress, appraisal, and coping. New York: Springer Publishing Company.

Lin, C. C., \& Yeh, Y. C. (2014). How gratitude influences well-being: a structural equation modeling approach. Social Indicators Research, 118(1), 205-217. doi: 10.1007/s11205013-0424-6

Listiyandini, R. A., Nathania, A., Syahniar,
D., Sonia, L., \& Nadya, R. (2015). Mengukur rasa syukur: Pengembangan model awal skala bersyukur versi Indonesia. Jurnal Psikologi Ulayat: Indonesian Journal of Indigenous Psyschology, 2(2), 473-496. doi: 10.24854/jpu22015-41

Loseby, P. (2019). Is stress affecting your physical and emotional wellbeing?. Diakses melalui https://www.sjog.org.au/news-andmedia/blog/2019/01/11/08/54/isstress-affecting-your-physical-andemotional-wellbeing (pada 28 Juli 20190

McMahon, A. T., Williams, P., \& Tapsell, L. (2010). Reviewing the meanings of wellness and well-being and their implications for food choice. Perspectives in Public Health, 130(6), 282-286. doi: 10.1177/1757913910384046

Mental Health Foundations . (2018). Mental health statistics: Stress. Diakses melalui https://www.mentalhealth.org.uk/sta tistics/mental-health-statistics-stress (pada 28 September 2018)

Nezlek, J. B., Krejtz, I., Rusanowska, M., \& Holas, P. (2018). Within-person relationships among daily gratitude, well-being, stress, and positive experiences. Journal of Happiness Studies, 20(3), 883-898. doi: 10.1007/s10902-018-9979-x

Papalia, D. E., Olds, S. W., Feldmen, R. D. (1998). Human development (Edisi ketujuh). United States: The McGraw-Hill Companies, Inc.

Prabowo, A. (2017). Gratitude dan psychological wellbeing pada remaja. Jurnal Ilmiah Psikologi Terapan, 5(2), 260. doi: $\underline{10.22219 / j i p t . v 5 i 2.4857}$

Riskesdas. (2018). Riset kesehatan dasar 2018. Jakarta: Kementerian Kesehatan Republik Indonesia.

Ryan, R. M., \& Deci, E. L. (2001). On 
happiness and human potentials : A review of research on hedonic and eudaimonic well-being. Annual Review of Psychology, 52(1), 141-166. doi: 10.1146/annurev.psych.52.1.141

Segal, J., Smith, M., Segal, R., \& Robinson, L. (2019). Stress symptoms, signs, and causes. Diakses melalui https://www.helpguide.org/articles/st ress/stress-symptoms-signs-andcauses.htm

Tennant, R., Hiller, L., Fishwick, R., Platt, S., Joseph, S., Weich, S., ... \& StewartBrown, S. (2007). The WarwickEdinburgh Mental Well-Being Scale (WEMWBS): Development and UK validation. Health and Quality of life Outcomes, 5(1), 63-75. doi: $\underline{10.1186 / 1477-7525-5-63}$

Ulfa, G. (2018). Hubungan antara stress, harga diri dan dukungan sosial terhadap kesejahteraan psikologis pada lanjut usia (Tesis tidak dipublikasikan). Surakarta: Universitas Muhammadiyah Surakarta

Widodo, R. I. (2018). Periode masa dewasa muda jadi masa paling stress. Diakses melalui https://www.republika.co.id/berita/g aya- hidup/trend/18/03/16/p5nxu5328periode-dewasa-muda-jadi-masapaling-stres (pada 8 Oktober 2018)

Wijaya, E. (2017). Peranan humor terhadap stres dengan subjective well being (SWB) sebagai mediator pada dewasa awal. Jurnal Muara Ilmu Sosial, Humaniora, dan Seni, 1(1), 353360. doi: $\underline{10.24912 / j m i s h u m s e n . v 1 i 1.377}$

Witvliet, C. V., Richie, F. J., Luna, L. M., \& Tongeren, D. R. (2018). Gratitude predicts hopea nd happiness: A two study assessment and states. The Journal of Positive Psychology, 14(3), 271-282. doi: $\underline{10.1080 / 17439760.2018 .1424924}$

Wood, A. M., Froh, J. J., \& Geraghty, A. W. (2010). Gratitude and well-being: A review and theoretical integration. Clinical Psychology Review, 30(7), 890905. doi: 10.1016/j.cpr.2010.03.005

World Health Organization (WHO). (2013). Mental health action plan 2013-2020. Switzerland: World Mental Health.

Zarbova, B., \& Karabeliova, S. (2018). Stress and well-being. Paper Conference, (January). 